\title{
Jarosław Kupczak OP, Teologiczna semantyka płci, Myśl Teologiczna 78, Kraków 2013, 250 s.
}

W książce tej autor omawia znaczenie ciała i płci jako ważnych sfer osoby ludzkiej. We wprowadzeniu przedstawia współczesne modne poglądy na ludzką płeć reprezentowane przez środowiska feministyczne i liberalne oraz pokazuje katolickie spojrzenie reprezentowane przez Benedykta XVI, a zwłaszcza Karola Wojtyłę - Jana Pawła II.

Rozdział I, zatytułowany Ciało a tożsamość osoby rozpoczyna się od prezentacji koncepcji Jeana Paula Sartre'a i Simone de Beauvoir: ich opisu ciała, teorii wolności i relacji międzyludzkich ujmowanych za pomocą kategorii konfliktu. Feminizm egalitarny uważa ciało za przeszkodę w budowaniu osobowej tożsamości. Natomiast feminizm różnicy reprezentowany przez Carol Giligan, Sylviane Agacinsky i Nel Noddings traktuje ciało jako pozytywny element tworzenia osobowej tożsamości. Dalej przedstawia chrześcijańską refleksję nad ciałem, które jest osobą, najpierw na podstawie pracy Karola Wojtyły Miłość i odpowiedzialność, potem odwołując się do katechez opartych na komentarzu do tekstów Księgi Rodzaju o stworzeniu pierwszych ludzi oraz ich upadku Mężczyzną i niewiastą stworzył ich. Zwraca uwagę między innymi na ważność „wymiany daru”, czyli wymiany czynności i bierności w miłości osób rodzaju męskiego i żeńskiego (s. 41) oraz na otwartość - odważne korzystanie z wiedzy biologicznej, seksuologicznej i medycznej dla wzbogacenia refleksji filozoficznej i teologicznej już w pierwszej, wydanej przed Soborem Watykańskim II pracy i w całym nauczaniu polskiego papieża (s. 44), który podkreśla także „osobowy sens ciała” (s. 47): "cielesno-materialno-biologiczny wymiar człowieka wyraża jego ducha” (s. 54).
Rozdział drugi nosi tytuł: Receptywność- kobiecy wymiar stworzenia. Rozpoczyna się przypomnieniem, że Louis Bouyer zwrócił uwage na teologiczne znaczenie odkryć twórcy psychoanalizy Sigmunda Freuda. Autor rozważa, w oparciu o prace Mircei Eliadego, związki cech płci z wyobrażeniami bóstw w różnych kulturach, jedność życia człowieka i jego płodności z życiem i płodnością całego kosmosu. Jest to dobry wstęp do stwierdzenia, że objawienie Starego i Nowego Testamentu, przynosząc całkiem nową treść, korzystało z dotychczasowego języka ówczesnych mitów (s. 61n).

Dalej omówiono rozumienie płci w myśli Platona i Arystotelesa, z których pierwszy przyznaje kobietom równą wartość i zdolności jak mężczyznom, leczw swej wizji idealnego państwa odrzuca małżeństwo i rodzinę, natomiast drugi uważa rozum kobiet za „niezbyt kompetentny” (s. 72). Jego myśl przyjęta przez św. Alberta Wielkiego i św. Tomasza z Akwinu wywarła wpływ na średniowieczną teologię scholastyczną. Nie było to zgodne z biblijną teorią płci, językiem płci w teologii biblijnej, która ukazuje równość mężczyzn i kobiet stworzonych na obraz Boga oraz potrzebę wzajemnego dopełniania się przez osoby obu płci: mężczyzn i kobiety. Stary Testament z wielkim szacunkiem odnosi się do rodziny i przekazywania życia, co sugeruje, że ludzka płodność odbija płodność Boga (s. 79). Prorocy przedstawiają związek Boga z Izraelem jako miłość oblubieńczą, małżeńską. Tak też rozumiano Pieśń nad Pieśniami. Uosobiona Mądrość jest jakby drugim ja Boga (s. 87), uzyskującym twarz kobiety. W Nowy Testamencie wcielony Bóg 
stał się mężczyzną, a nowy Lud Boży Jego umiłowaną oblubienicą.

Autor przedstawia spór o rozumienie receptywności jako cechy kobiecej i podkreśla znaczenie fenomenologicznej analizy płci Edyty Stein - św. Teresy Benedykty od Krzyża (sfera duchowa musi być zakorzeniona w cielesności, a cielesność wyrażać to, co duchowe) oraz personalistycznej filozofii Gabriela Marcela (zwraca on uwagę na receptywność jako postawę zarówno mężczyzny, jak i kobiety - otwartości i gotowości przyjęcia całej rzeczywistości, zwłaszcza innych osób i Boga). Autor omawia też uzupełnienie Tomaszowej antropologii o dynamiczny wymiar relacyjności i receptywności (s. 100) i przedstawia opinie współczesnych autorów rozwijających problem w duchu chrześcijańskim.

Rozdział trzeci: Teo-ontologia płci - teologiczna interpretacja płci, jej natury jako ważnego elementu osoby ludzkiej, zawiera analizę koncepcji Paula Evdokimova (jedność męskości i kobiecości w Chrystusie) oraz Hansa Ursa von Balthasara (męskośći kobiecość w tajemnicy trynitarnej). Rozważania obu wybitnych teologów pozwalają głębiej spojrzeć na ludzką płeć jako odbicie największych prawd wiary chrześcijańskiej. Uzupełnia je koncepcja Davida L. Schindlera, dostrzegającego znaczenie teo-ontologii płci w debacie o Kościele. W tym kontekście autor interpretuje dokumenty o dopuszczeniu do kapłaństwa służebnego wyłącznie mężczyzn z 1976 i z 1994 roku z komentarzem Josepha Ratzingera oraz wypowiedzi Karola Wojtyły - Jana Pawła II na temat ojcostwa, roli kobiety w planie zbawienia i znaczenia dziecka w rodzinie.

Ostatni rozdział nosi tytuł Spór o Boga Ojca. Zawiera krytyczną analizę książki amerykańskiej feministki Elizabeth Johnson $\mathrm{Ta}$, która jest. Tajemnica Boga w feministycznym i teologicznym dyskursie oraz jako kontrpropozycję wobec jej koncepcji prezentuje stanowisko przedstawione w dramacie Karola Wojtyły Promieniowanie ojcostwa z 1964 roku. Wykazuje metodologiczne błędy, narzucanie obcej hermeneutyki tekstom biblijnym, lekkomyślność argumentacji i niekonsekwencje autorki głoszącej detronizację ojca, jednostronność postulatu traktowania doświadczenia kobiet jako zasady teologicznej rekonstrukcji, krytykę androcentrycznej symboliki, dekonstrukcję androcentrycznej chrystologii, kobiecą symbolikę trynitarną, proponowane zarysy feministycznej rekonstrukcji teologii trynitarnej. Przeciwstawia tej koncepcji myśl Karola Wojtyły, który w swym dramacie pokazuje samotność i ojcostwo jako dwie alternatywne antropologie, snuje głębokie rozważania na temat dziecka i niewiasty (matki), ,, dokonuje refleksji nad najbardziej podstawowymi rzeczywistościami w życiu każdego człowieka”, jakimi są: „ojciec, matka, dziecko, rodzenie, tożsamość osoby, miłość, samotność, więź" (s. 213). W końcowych uwagach autor analizuje myśl Massimo Serrettiego oraz Emmanuela Levinasa na temat współczesnych pokus absolutyzacji człowieka oraz przekraczanie swej samotności w kontaktach z innymi osobami oraz Stanisława Grygiela analizującego różnice między ojcostwem i macierzyństwem w spostrzeżeniach Wojtyły i Levinasa.

Ostatnią część książki - Zamiast zakończenia można uznać za syntetyczne przedstawienie "nowego feminizmu" Jana Pawła II, w którym równa godność mężczyzny i kobiety, szacunek dla różnic między nimi i powołanie do wzajemnego uzupełniania się ukazują człowiekowi sens i cel jego istnienia. Pozwala to też nieco wniknąć w tajemnice jedności Osób Trójcy Przenajświętszej, Kościoła jako oblubienicy Chrystusa i Maryi 
przyjmującej Boże zaproszenie do udziału w zbawieniu i zjednoczonej z Chrystusem jako wzoru dla każdego człowieka.

Bibliografia zawiera wartościowe pozycje w kilku językach. Indeks osób oraz indeks rzeczowy pozwalają szybko odnaleźć pozycje wykorzystywane $w$ pracy oraz omawiane zagadnienia.

Rozprawa pokazuje wielką erudycję autora, głębokie zrozumienie czytanych tekstów, zarówno wartościowych, jak i modnych, choć opartych na słabych podstawach. Jest cennym głosem w dyskusji o roli płci i god- ności człowieka, odpowiedzią na głośno podnoszone hasła prowadzące do wewnętrznego rozbicia indywidualnych osób ludzkich, rodzin i całych społeczności. Dzieło świadczy o tym, że jego autor bardzo dobrze zna problematykę człowieka, ludzkiego ciała, umie nawiązać twórczy dialog z myślą współczesną, jest wrażliwym i głębokim myślicielem i teologiem, umie w sposób jasny przekazywać trudne zagadnienia interesujące każdego myślącego człowieka.

Tomasz Dąbek OSB 